Conference Paper

\title{
The Role of Ampo As an Adsorbent for Reducing Peroxide Value in Used Cooking Oil
}

\author{
Susilowati*, Khanza Lolita Astya, Ulinnuha Syaiful Bachri \\ Department of Chemical Engineering, Engineering Faculty, Universitas Pembangunan Nasional "Veteran" \\ Jawa Timur, Indonesia
}

*Corresponding author:

E-mail: zuzisukasno@gmail.com

\begin{abstract}
In daily life, cooking oil has a very important role. Cooking oil itself has a usage limit. If the cooking oil has a rancid smell and turns brown, the cooking oil is not suitable for reuse. Naturally, cooking oil can only be used 2-3 times. To extend the life of cooking oil and improve its quality so that it can be reused, an adsorption process is carried out to adsorb harmful substances in used cooking oil. In this research, Ampo adsorbent is used which has the advantage of being environmentally friendly and edible. The procedures carried out in this study include the initial analysis of used cooking oil, activation of the Ampo as an adsorbent, the adsorption process by varying the mass of Ampo 70, 75, 80, 85, 90 grams and stirring time of 30, 60, 90, 120, 150 minutes and analysis of peroxide value on the adsorbed used cooking oil. The optimal condition of the research is that for the adsorption process using Ampo as adsorbent on used cooking oil, namely by stirring for 60 minutes and Ampo mass of 75 grams. This condition can reduce the peroxide value by up to $93 \%$. While the maximum adsorption power of the Ampo adsorbent was obtained from the proving of the Freundlich isotherm equation theory with a value of $14,6487 \mathrm{mg} / \mathrm{gram}$.
\end{abstract}

Keywords: Adsorption, Ampo, Peroxide value, and Used cooking oil

\section{Introduction}

Cooking oil is an organic lipid that is often used for frying food. Generally, cooking oil can only be used 2-3 times in the frying process. Used cooking oil that is no longer suitable for use has physical characteristics, it smells rancid, brown in color, and if you feel it, it will cause a cough in the throat. The rest of the cooking oil is not suitable for use because after going through the frying process many times there will be a chemical reaction in the cooking oil which produces toxic compounds in the body.

These reactions are a form of oxidation, polymerization, and hydrolysis reactions. The oxidation reaction is the formation of cyclic peroxide and monomer groups which will increase the amount of peroxide contained (Mardiyah, 2018). The amount of peroxide increasing in the oil can be expressed as the number of peroxides. While the polymerization reaction is a reaction that forms polymer compounds during the frying process and the hydrolysis reaction itself is caused by the large amount of water contained in the oil.

An increase in the amount of peroxide is one of the main causes of rancidity, discoloration, and the production of toxins in oil. Some of these oxidations involve several types of free radicals and oxygen. The peroxide value is generally used for the measurement of unwanted reactions in food and oil ingredients (Dermis, 2012). The peroxide value has a maximum limit value of $10 \mathrm{meq} / \mathrm{kg}$. Packaged cooking oil on the market has an average peroxide value of $1-2 \mathrm{meq} / \mathrm{kg}$. The increase in the number of peroxide in used cooking oil is also bad for health because it can cause liver damage and cancer in the body (Suroso, 2013).

\section{How to cite:}

Krishanti, N. P. R. A., Zulfiana, D., \& Wikantyoso, B. (2021). The role of ampo as an adsorbent for reducing peroxide value in used cooking oil. $5^{\text {th }}$ International Seminar of Research Month 2020. NST Proceedings. pages 22-29. doi: $10.11594 /$ nstp.2021.0905 
To reduce the peroxide value in used cooking oil, a physical adsorption process is carried out to adsorb peroxides and toxic compounds in the oil. The basic principle of adsorption is the implementation of the mass transfer process, both the adsorption of molecules from liquids and gases to the surface of solid objects (Gawande et al., 2017). In this study, we used Ampo which is a traditional Tuban snack made of clay.

The reason for choosing Ampo as an adsorbent is because clay has a large surface area, physical and mechanical stability, and a regular layer structure. Also, the low costs required for processing are an advantage of using Ampo as an adsorbent. Before being used as an adsorbent, Ampo will first be activated so that the pores on the surface of the Ampo open so that it can adsorb more adsorbate.

According to Sera et al. (2019) adsorption is influenced by several factors as follows:

1. Adsorbent Particle Size: If the size of the adsorbent particles is getting smaller, the larger the surface area of the adsorbent will cause a fast diffusion rate and more substances will be adsorbed.

2. Contact Time: An adsorption process requires sufficient contact time between the adsorbate and the adsorbent until the adsorption equilibrium occurs.

3. Adsorbate Concentration: The more adsorbate being absorbed will increase the adsorption rate.

4. Adsorbate Molecular Size: In adsorption, the size of the adsorbate molecule is expected to be smaller than the pore diameter of the adsorbent to create a strong attractive force that causes the adsorption rate to be high.

5. Polarity of Substance: For non-polar adsorbents such as activated charcoal, the nonpolar adsorbate molecules will be stronger to adsorb than polar molecules. Examples of non-polar adsorbates are methanol, ethanol, hydrocarbon groups.

6. Temperature: Temperature can increase the rate at which the material will be adsorbed. But too high a temperature can cause desorption because desorption occurs at high temperatures.

7. Mixing: The degree of stirring can affect the diffusion of the film because of the process of crushing the film layers between the adsorbent surfaces.

\section{Langmuir Isotherm}

Langmuir derived the theory of adsorption isotherms by using a simple model of a solid which adsorbs gas on its surface. This model defines that the maximum adsorption capacity occurs due to the presence of a monolayer of adsorbate on the adsorbent surface.

Langmuir isotherm equation is mathematically expressed as

$$
\begin{aligned}
& X m / m=\frac{a . c}{1+b . c} . \\
& m \cdot c / X m=1 / a+(b / a) \cdot c
\end{aligned}
$$

Where:

$\mathrm{Xm} \quad=$ mass of adsorbate

$\mathrm{m} \quad=$ mass of adsorbent (Ampo)

$\mathrm{C}=$ equilibrium concentration of a substance in solution

By making the m.c/Xm curve against $\mathrm{C}$, a linear equation will be obtained with an intercept of $1 / a$ and slope $(b / a)$, so that the values of $a$ and $b$ can be calculated, from the size of the values $a$ and $\mathrm{b}$ that indicating the adsorption power. 


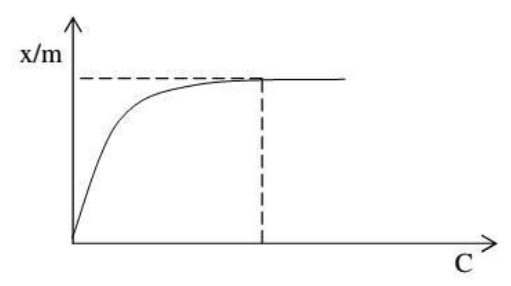

Figure 1. Langmuir adsorption isotherm curve (Handayani \& Sulistyanto, 2009)

\section{Freundlich isotherm}

Freundlich isotherm model is used for non-ideal adsorption and is multilayer adsorption. The relationship between the amount of substance adsorbed and the concentration is shown in Equation 4 (Misran et al., 2016).

$$
\begin{gathered}
\frac{X m}{m}=k \cdot C^{1 / n} \\
\log \frac{X m}{m}=\log K+\frac{1}{n} \log C
\end{gathered}
$$

Where:

$\mathrm{Xm} \quad=$ mass of adsorbate

$\mathrm{m} \quad=$ mass of adsorbent (Ampo)

$\mathrm{C}=$ equilibrium concentration of a substance in solution

Then $\mathrm{k}$ and $\mathrm{n}$ are the adsorption constants whose value depends on the type of adsorbent and the adsorption temperature. If a $\log$ curve $(\mathrm{Xm} / \mathrm{m})$ is made against $\log \mathrm{C}$, a linear equation will be obtained with a $\log \mathrm{k}$ intercept and a slope of $1 / \mathrm{n}$, so that the values of $\mathrm{k}$ and $\mathrm{n}$ can be calculated.

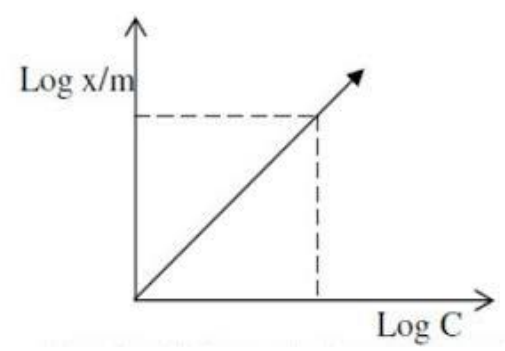

Figure 2. Freundlich adsorption isotherm curve (Handayani, 2009)

\section{Material and Methods}

This research was conducted at the Research Laboratory of the Department of Chemical Engineering UPN “Veteran" East Java. The study began in Mei 2020 until August 2017. In this research materials used are Ampo, Used Cooking Oil, $1 \mathrm{~N}$ Citric Acid, and Aquadest. Ampo is obtained from Trowulan Hamlet, Tuban, East Java, and used cooking oil is obtained from fried bread seller at Pasar Pacuan Kuda, Surabaya. The equipment used in this study, namely a series of stirrers including magnetic stirrer and beaker glass. The variables used in this study were the Ampo mass of $70,75,80,85,90$ grams and the stirring time of $30,60,90,120,150$ minutes. 


\section{Research Procedure}

\section{Adsorbent Activation}

Ampo is crushed to 60 mesh then washed with water and dried. Then crush the Ampo again to 60 mesh and activated the Ampo with $1 \mathrm{~N}$ citric acid solution using a magnetic stirrer. Then it is filtered and the Ampo is dried in an oven then crush the Ampo to 60 mesh size.

\section{Adsorbent Application in Used Cooking Oil}

Put the Ampo into the used cooking oil and stir it. Ampo mass and stirring time were adjusted according to the research variables The results are filtered and separated, Then the obtained filtrate is analyzed for its peroxide value..

\section{Results and Discussion \\ Results}

Research on reducing the peroxide value in used cooking oil using Ampo adsorbent was carried out to prove the theory that activated Ampo can be used to reduce the peroxide value in used cooking oil. Ampo was activated with $1 \mathrm{~N}$ citric acid and dried in an oven and then mashed to 60 mesh size. Ampo that has been activated is then applied to used cooking oil by stirring for 30, 60, 90, 120, and 150 minutes and the adsorbent mass of Ampo as much as 70, 75, 80, 85, and 90 grams. The operating conditions specified for the application of the adsorbent were stirring temperature of $50{ }^{\circ} \mathrm{C}$, stirring speed of $300 \mathrm{rpm}$, the volume of used cooking oil $200 \mathrm{ml}$, and the adsorbent particle size of 60 mesh.

\section{Percent Decrease in Peroxide Value}

The research results obtained peroxide value data by testing with the titrimetric method at the Food Analysis Laboratory of the Univesitas Pembangunan Nasional "Veteran" Jawa Timur. From the analysis that has been obtained, the following is a graph of the analysis results of the reduction in peroxide values in this study.

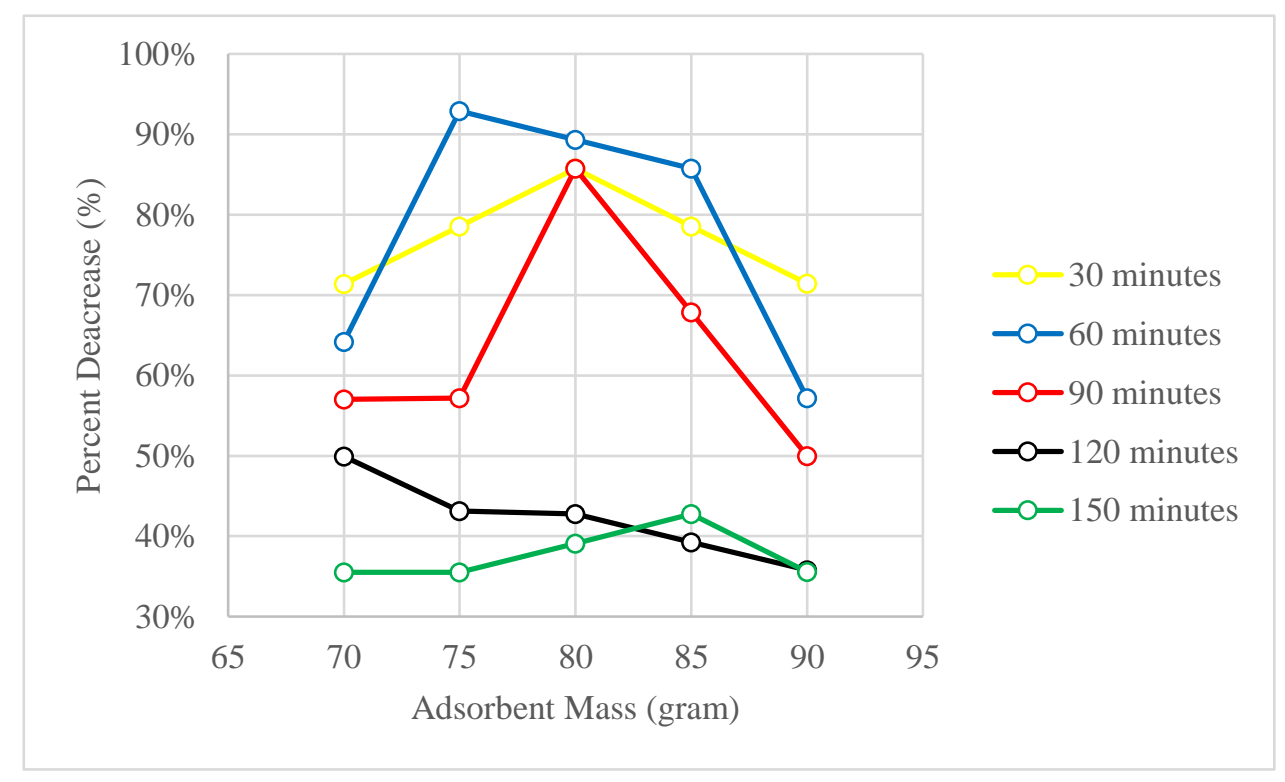

Figure 3. Graph of Ampo Adsorbent Mass vs Percent Decrease in Peroxide Value 
The graph above shows the percentage reduction in the peroxide value of used cooking oil using Ampo adsorbent at mass variables of 70, 75, 80, 85, 90 grams and time 30, 60, 90, 120, 150 minutes. The peroxide value of used cooking oil before adsorption is $13,94 \mathrm{meq} / \mathrm{kg}$. The peroxide value of used cooking oil after being adsorbed with the Ampo adsorbent at a stirring time of 30 minutes with the adsorbent mass of 70 grams, 75 grams, 80 grams, 85 grams, and 90 grams respectively is 3,99 meq/kg; 0,99 meq $/ \mathrm{kg} ; 1,99 \mathrm{meq} / \mathrm{kg} ; 2,99 \mathrm{meg} / \mathrm{kg}$; and 3,98 meq $/ \mathrm{kg}$. The peroxide value of used cooking oil after being adsorbed with Ampo adsorbent at 60 minutes stirring time with the adsorbent mass of 70 grams, 75 grams, 80 grams, 85 grams, and 90 grams respectively is $4,99 \mathrm{meq} / \mathrm{kg} ; 0,99 \mathrm{meq} / \mathrm{kg} ; 2,49 \mathrm{meq} / \mathrm{kg} ; 1,99 \mathrm{meq} / \mathrm{kg}$; and $5,97 \mathrm{meq} / \mathrm{kg}$. The peroxide value of used cooking oil after being adsorbed with Ampo adsorbent at 90 minutes stirring time with the adsorbent mass of 70 grams, 75 grams, 80 grams, 85 grams, and 90 grams respectively is $5,99 \mathrm{meq} / \mathrm{kg} ; 5,97 \mathrm{meq} / \mathrm{kg} ; 1,99 \mathrm{meq} / \mathrm{kg} ; 4,48 \mathrm{meq} / \mathrm{kg}$; and 6,97 meq $/ \mathrm{kg}$. The peroxide value of used cooking oil after being adsorbed with Ampo adsorbent at 120 minutes stirring time with the adsorbent mass of 70 grams, 75 grams, 80 grams, 85 grams, and 90 grams respectively is 6,98 meq/kg; 7,93 meq/kg; 7,98 meq/kg; 8,47 meq/kg; and 8,95 meq $/ \mathrm{kg}$. The peroxide value of used cooking oil after being adsorbed with Ampo adsorbent at 150 minutes stirring time with the adsorbent mass of 70 grams, 75 grams, 80 grams, 85 grams, and 90 grams respectively is 8,99 meq/kg; 8,99 meq/kg; 8,49 meq/kg; 7,98 meq/kg; and 8,98 meq $/ \mathrm{kg}$.

In this study, the best condition for adsorption is the stirring time of 60 minutes with an Ampo adsorbent mass of 75 grams. This condition gives a peroxide value of $0,99 \mathrm{meq} / \mathrm{kg}$, which means that there is a decrease in the peroxide value by $93 \%$. These results are following SNI 3741-2013 that the maximum is $1 \mathrm{meq} / \mathrm{kg}$. It can be concluded that the adsorbent mass and stirring time affect the reduction in the peroxide value of cooking oil.

\section{Calculation of langmuir and freundlich isotherms}

The calculation of the adsorption isotherm suitable for the peroxide absorption process by the Ampo adsorbent is carried out by calculating using the Langmuir and Freundlich equations. Langmuir equation calculations are done using the following equation.

$$
\mathrm{Ce} /(\mathrm{x} / \mathrm{m})=1 / \mathrm{ab}+1 / \mathrm{a} \mathrm{Ce}
$$

Meanwhile, the calculation of the Freundlich equation is using the following equation.

$$
\log (\mathrm{x} / \mathrm{m})=\log \mathrm{k}+1 / \mathrm{n} \log \mathrm{Ce}
$$

$\mathrm{Ce}=$ peroxide concentration in the oil after absorption.

$\mathrm{x} / \mathrm{m}=$ peroxide mass adsorbed per gram of adsorbent Ampo.

$\mathrm{b} \quad=$ langmuir number.

$\mathrm{a} \& \mathrm{k} \quad=$ maximum adsorption capacity $(\mathrm{mg} / \mathrm{gram})$

The values of a and $\mathrm{k}$ indicate the capacity of peroxide adsorption by the Ampo adsorbent, the greater the value in the Langmuir Isotherm equation and the Freundlich Isotherm equation, the greater the adsorption capacity. The value of $1 / \mathrm{ab}$ and $\log \mathrm{k}$ is influenced by temperature so that it affects the adsorption rate. To determine the Langmuir and Fruendlich isotherm equation, the values of $\mathrm{x} / \mathrm{m}, \mathrm{Ce} /(\mathrm{x} / \mathrm{m}), \log \mathrm{Ce} /(\mathrm{x} / \mathrm{m})$, and $\log$ Ce are calculated. 
Table 1. Calculation of the value of $\mathrm{x} / \mathrm{m}, \mathrm{Ce} /(\mathrm{x} / \mathrm{m}), \log (\mathrm{x} / \mathrm{m})$ and $\log \mathrm{Ce}$

\begin{tabular}{|c|c|c|c|c|c|c|}
\hline \multirow{2}{*}{$\begin{array}{l}\text { Stirring } \\
\text { Time } \\
\text { (minutes) }\end{array}$} & \multirow{2}{*}{$\begin{array}{c}\text { Mass } \\
\text { (gram) }\end{array}$} & \multirow{2}{*}{$\mathrm{X} / \mathrm{m}$} & \multicolumn{2}{|c|}{ Langmuir } & \multicolumn{2}{|c|}{ Freundlich } \\
\hline & & & $\mathrm{Ce}(\mathrm{ppm})$ & $\mathrm{Ce} /(\mathrm{x} / \mathrm{m})$ & $\log \mathrm{Ce}$ & $\log (x / m)$ \\
\hline \multirow{5}{*}{30} & 70 & 2,4175 & 67,8593 & 28,0703 & 1,8316 & 0,3834 \\
\hline & 75 & 2,4831 & 50,8520 & 20,4794 & 1,7063 & 0,3950 \\
\hline & 80 & 2,5405 & 33,8446 & 13,3222 & 1,5295 & 0,4049 \\
\hline & 85 & 2,1909 & 50,8520 & 23,2100 & 1,7063 & 0,3406 \\
\hline & 90 & 1,8821 & 67,6893 & 35,9638 & 1,8305 & 0,2747 \\
\hline \multirow{5}{*}{60} & 70 & 2,1745 & 84,8667 & 39,0279 & 1,9287 & 0,3374 \\
\hline & 75 & 2,9366 & 16,8373 & 5,7336 & 1,2263 & 0,4678 \\
\hline & 80 & 2,6468 & 25,3410 & 9,5743 & 1,4038 & 0,4227 \\
\hline & 85 & 2,3910 & 33,8446 & 14,1548 & 1,5295 & 0,3786 \\
\hline & 90 & 1,5061 & 101,5339 & 67,4153 & 2,0066 & 0,1779 \\
\hline \multirow{5}{*}{90} & 70 & 1,9315 & 101,8740 & 52,7421 & 2,0081 & 0,2859 \\
\hline & 75 & 1,8073 & 101,5339 & 56,1794 & 2,0066 & 0,2570 \\
\hline & 80 & 2,5405 & 33,8446 & 13,3222 & 1,5295 & 0,4049 \\
\hline & 85 & 1,8928 & 76,1929 & 40,2537 & 1,8819 & 0,2771 \\
\hline & 90 & 1,3171 & 118,5412 & 90,0000 & 2,0739 & 0,1196 \\
\hline \multirow{5}{*}{120} & 70 & 1,6910 & 118,7113 & 70,2011 & 2,0745 & 0,2281 \\
\hline & 75 & 1,3629 & 134,8683 & 98,9600 & 2,1299 & 0,1345 \\
\hline & 80 & 1,2670 & 135,7187 & 107,1141 & 2,1326 & 0,1028 \\
\hline & 85 & 1,0945 & 144,0523 & 131,6179 & 2,1585 & 0,0392 \\
\hline & 90 & 0,9430 & 152,2158 & 161,4228 & 2,1825 & $-0,0255$ \\
\hline \multirow{5}{*}{150} & 70 & 1,2027 & 152,8961 & 127,1313 & 2,1844 & 0,0801 \\
\hline & 75 & 1,1225 & 152,8961 & 136,2121 & 2,1844 & 0,0502 \\
\hline & 80 & 1,1586 & 144,3924 & 124,6238 & 2,1595 & 0,0639 \\
\hline & 85 & 1,1925 & 135,7187 & 113,8087 & 2,1326 & 0,0765 \\
\hline & 90 & 0,9373 & 152,7260 & 162,9435 & 2,1839 & $-0,0281$ \\
\hline
\end{tabular}

The strain S. prasinopilosus Pn-TN2 which isolated from termite nest sample, showed a broad range of antimicrobial activity against bacterial and fungal test. Result showed that this isolate possessed inhibition rate

From the table above, graph mapping is carried out using Excel by plotting the value of $\mathrm{Ce} /(\mathrm{x} / \mathrm{m})$ versus Ce to get the Langmuir equation and plotting $\log (\mathrm{x} / \mathrm{m})$ versus log Ce to get the Freundlich equation. Mapping results with graphs as shown in the figure 4 and 5. 


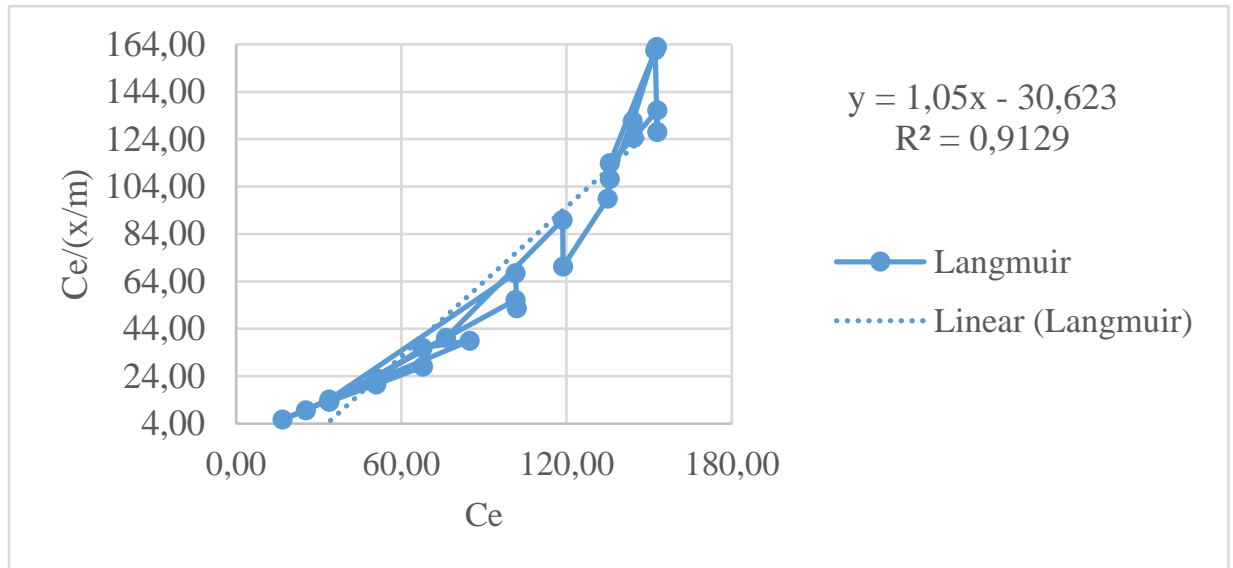

Figure 4. Langmuir Isotherm Adsorption Equation of Ce vs Ce/(x/m)

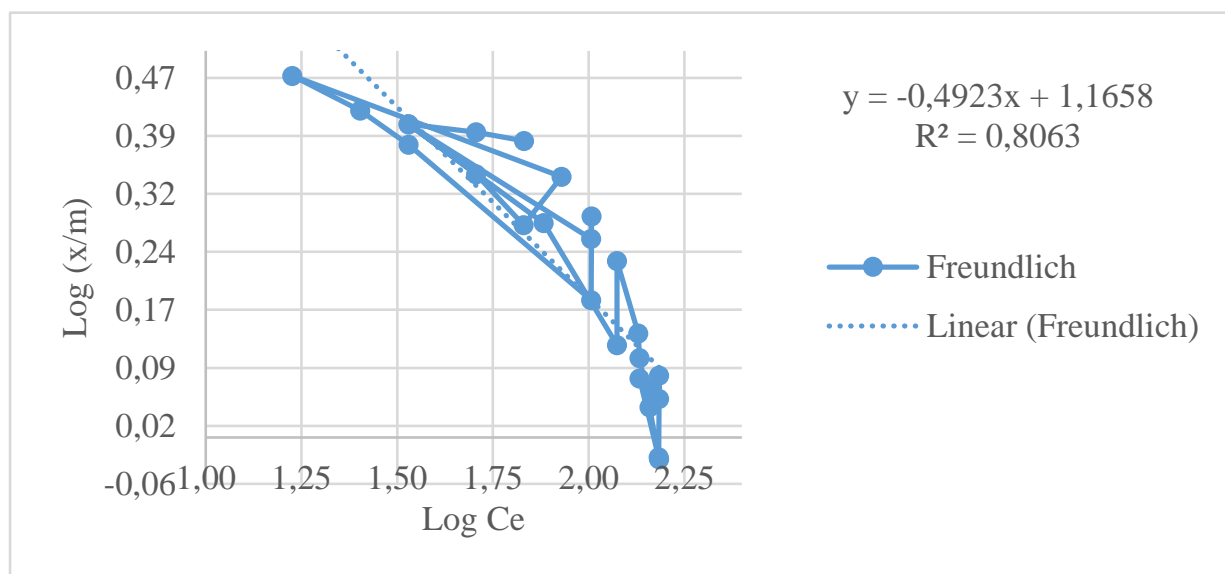

Figure 5. Freundlich Adsorption Isotherm equation of $\log$ Ce vs $\log (\mathrm{x} / \mathrm{m})$

The constant values of the above equations are shown in Table 2.

Table 2. Langmuir and Freundlich isotherm constants values

\begin{tabular}{ccc}
\hline Isoterm & Constant & Value \\
\hline \multirow{2}{*}{ Langmuir } & $\mathrm{a}$ & 0,9524 \\
& $\mathrm{~b}$ & 0,0343 \\
\multirow{2}{*}{ Freundlich } & $\mathrm{k}$ & 14,6487 \\
& $\mathrm{n}$ & 2,0313 \\
\hline
\end{tabular}

To determine the maximum adsorption capacity that occurs in the adsorption process using an Ampo adsorbent, it can be determined by the Langmuir and Freundlich isotherm equation. The results of the Freundlich equation show that the maximum adsorption capacity is 14,6487 $\mathrm{mg} / \mathrm{gram}$.

\section{Conclusion}

The results of the study can be concluded that:

1. The adsorption process of used cooking oil with Ampo adsorbent can reduce the value of the peroxide value where the stirring time and the adsorbent mass are influential variables in the study. The best results were obtained under the stirring time for 60 minutes with an Ampo adsorbent mass of 75 grams. This condition gives a peroxide 
value of $0,99 \mathrm{meq} / \mathrm{kg}$, which means that there is a decrease in the peroxide value by 93\%. These results are following SNI 3741-2013 that the maximum is $1 \mathrm{meq} / \mathrm{kg}$.

2. Research shows that the maximum adsorption capacity of the Ampo adsorbent is $14,6487 \mathrm{mg} / \mathrm{gram}$.

3. The peroxide adsorption equation by Ampo has fulfilled the Langmuir equation with $\mathrm{R} 2=0,9129$ and the Freundlich equation with $\mathrm{R} 2=0,8063$

\section{Acknowledgment}

The author would like to thank our parents for their endless support and guidance until we finished this research. We also want to thank our friends who always sharing their knowledge with us during this research.

\section{References}

Dermiş, S., Can, S., \& Doru, B. (2012). Determination of peroxide values of some fixed oils by using the mFOX method. Spectroscopy Letters, 45(5), 359-363. https://doi.org/10.1080/00387010.2012.666702

Gawande, S. M., Belwalkar, N. S., \& Mane, A. A. (2017). Adsorption and its Isotherm - Theory. International Journal of Engineering Research, 6(6), 312. doi: 10.5958/2319-6890.2017.00026.5

Handayani, M., \& Sulistyono, E. (2009). Uji Persamaan Langmuir dan Freundlich pada Penyerapan Limbah Chrom (VI) Oleh Zeolit. Prosding Seminar Nasional Sains dan Teknologi Nuklir.

Mardiyah, S. (2018). Efek Anti Oksidan Bawang Putih Terhadap Penurunan Bilangan Peroksida Minyak Jelantah. The Journal of Muhammadiyah Medical Laboratory Technologist. 1(2), 98-110.

Misran, E., Panjaitan, F., \& Yanuar, F. M. (2016) Pemanfaatan Karbon Aktif dari Ampas Teh sebagai Adsorben pada Proses Adsorbsi $\beta$ Karoten yang Terkandung dalam Minyak Sawit Mentah. Jurnal Rekayasa Kimia dan Lingkungan, 11(2), 94.

Sera, R., Lesmana, D., \& Maharani, A. (2019). The Influence of Temperature and Contact Time on Waste Cooking Oil's Adsorption Using Bagasse Adsorbent. Inovasi Pembangunan: Jurnal Kelitbangan, 7(2), 181.

Suroso, A. S. (2013). Kualitas minyak goreng habis pakai ditinjau dari bilangan peroksida, bilangan asam, dan kadar air. Jakarta: Kemenkes RI. 